\title{
Investigation comparatively of different external central steel braced frame behaviours with ductility level high and limited
}

\author{
Süneklik düzeyi yüksek ve sınırl farklı dış merkezi çelik çaprazlı çerçeve davranışlarının \\ karşılaştırmalı incelenmesi
}

\author{
Şenol GÜRSOY ${ }^{* 1, a}$, Ayşegül YILMAZ2,b \\ ${ }^{1}$ Karabük University, Faculty of Engineering, Department of Civil Engineering, 78050, Karabük \\ ${ }^{2}$ Karabük University, Graduate Education Institute, Department of Civil Engineering, 78050, Karabük
}

• Geliş tarihi / Received: 18.04.2021 • Düzeltilerek geliş tarihi / Received in revised form: 07.06.2021 • Kabul tarihi / Accepted: 17.06 .2021

\begin{abstract}
In steel structures to prevent horizontal displacement and deformations due to loads such as especially earthquake and wind are used various types of diagonal element. This matter reveals the importance of selection the right steel structural system suitable for the purpose. On the other hand, steel structures according to the Turkey Earthquake Building Regulation must be ductile to consume the earthquake energy. The objective of this study when this is the case are investigated comparatively the behaviours of steel structures with different external central steel braced the ductility level high and ductility level limited according to Turkey Earthquake Building Regulations. The findings obtained from the structural analyses carried out with the Sta-Steel program reveal that different external central steel braced structure models with ductility level high behave better than structural models with ductility level limited and different external central braces that increase the structure lateral stiffness increase the performance of the said structure. Also, the base shear force values of the ductility level limited external central steel braced structure models are larger than the ductility level high and external central steel braced structure models. It shows that these obtained findings in terms of the steel structures safety to be constructed in Turkey it would be more rational to prefer the steel structural systems with ductility level high steel brace members.
\end{abstract}

Keywords: Ductility level, External central steel braced frames, Sta-Steel, Steel structures

$\ddot{\boldsymbol{O}} \boldsymbol{z}$

Çelik yapılarda özellikle deprem ve rüzgâr gibi yükler nedeniyle yatay yerdeğiştirme ve şekildeğiştirmeleri engellemek için çeşitli diyagonal elemanlar tipleri kullanılmaktadır. Bu husus amaca uygun doğru çelik taşıyıcı sistem seçiminin önemi ortaya koymaktadır. Diğer taraftan Türkiye Bina Deprem Yönetmeliğine göre çelik yaplların deprem enerjisini tüketebilmeleri için sünek olmaları gerekmektedir. Durum böyle olunca bu çalışmanın amacı Türkiye Bina Deprem Yönetmeliğine göre süneklik düzeyi yüksek ve süneklik düzeyi sınırlı farklı dış merkezi çelik çaprazlara sahip çelik yapıların davranışlarını karşılaştırmalı olarak incelemektir. Sta-Steel programıyla gerçekleştirilen yapısal çözümlemelerden elde edilen bulgular, süneklik düzeyi yüksek farklı dış merkezi çelik çaprazlı yapı modellerinin süneklik düzeyi sınırlı yapı modellerinden daha iyi davrandı̆̆ını ve yapı yanal rijitliği artıran farklı dış merkezi çaprazların söz konusu yapının performansını arttırdığını ortaya koymaktadır. Ayrıca süneklik seviyesi sınırlı dış merkezi çelik çaprazlı yapı modellerinin taban kesme kuvveti değerleri, süneklik seviyesi yüksek ve dış merkezi çelik çaprazlı yapı modellerinden daha büyük olmaktadır. Elde edilen bu bulgular Türkiye'de inşa edilecek çelik yapıların emniyeti bakımından süneklik düzeyi yüksek çelik çapraz elemanlara sahip çelik taşıyıcı sistemlerin tercih edilmesinin daha rasyonel olacağını göstermektedir.

Anahtar kelimeler: Süneklik düzeyi, Dış merkezi çelik çaprazlı çerçeveler, Sta-Steel, Çelik yapılar

\footnotetext{
*a Şenol GÜRSOY; sgursoy@karabuk.edu.tr; Tel: (0370) 418 70 60; orcid.org/0000-0001-8133-0906

${ }^{\mathrm{b}}$ orcid.org/0000-0002-1126-0743
} 


\section{Introduction}

Structural systems in steel structures are formed by combining columns and beams, if any, diagonal elements to each other in various ways. Loads affecting a steel structure are also met by these frame systems. On the other hand, different diagonal elements are used to strengthen the steel frame systems formed by combining columns and beams against horizontal load effects such as especially earthquakes. Because in steel frames, the displacements of diagonal elements between storeys decrease and the lateral rigidity of the said structure increases (Gönen, 1997; Ay vd., 2010; Ay and Çelik, 2012; Özçelik, 2016; Yelgin ve Bulut, 2016; Akgönen, 2017; Çavdar, 2017; Arıbaş vd., 2019; Bayram vd., 2019; Çavdar, 2019). In addition, diagonal elements contribute to the energy damping and load distribution of the said structure. In summary, diagonal elements contribute positively to the reduction of damage to steel structures, especially from earthquakes, thus improving their behaviour.

Steel structural elements in Turkey are expected to show adequate performance against horizontal loads. Today, the strength of steel structural systems against earthquakes and their energy damping can be provided by designs to be carried out in accordance with the design conditions specified in the regulations. The concept of capacity for dimension a steel structure is used. In other words, steel structures are sized according to the capacities of the parts that ductile. In a steel structure under the effect of horizontal loads, the said loads can be met with different frame types such as moment-transmitting steel frames, central steel braced frames and external central steel braced frames.

The main purpose of this article is to examine comparatively the effects on the behaviour of the said structure of different external central steel cross types, which are widely used to increase the resistance against earthquakes of steel structures of Ductility Level High (DLH) and Ductility Level Limited (DLL). Thus, it is aimed to better understand the effect of the structure ductility level on the structure behaviour. For this purpose, DLH and DLL steel structure models with different external central steel braced types are created and structural analyses of these models is made with the Sta-Steel program (Sta-Steel, 2019). Results are presented by comparing the findings obtained from the structural analyses with each other.

\section{Design principles of steel structure according to Turkish building earthquake regulations}

Structural systems of steel structures according to the horizontal loads in the Turkey Building Earthquake Code (TBEC) in terms of seismic behaviour, ductility level high, ductility level limited and ductility level hybrid is divided into three classes, including systems (TBEC, 2019). The structural system behaviour (ductility) coefficient (R) and strength excess coefficient (D) and the permissible building height classes (BYS) to be used in the design of the said systems according to earthquakes are given in Table 1 .

In TBEC, approaches aiming to design steel structures as resistant all predicted load effects, including earthquakes, are divided into two as the application of design with safety coefficients (GKT) and design with load-resistance coefficients (YDKT) methods. According to this regulation, steel structural systems are required to have sufficient ductility, to be able to make nonlinear deformation, and to avoid brittle collapse mechanisms in the structural elements and / or the structural system during plastic deformation. In the aforementioned regulation, the regions of the structural systems carrying high ductility level horizontal loads whose capacity is preserved; The plastic hinge regions in moment-transmitting frames consist of the transverse beams of the external central braced frames and the end and middle combinations of the cross members of the central braced frames (see Figure 1).

Steel structure elements designed as DLH and DLL in TBEC must be designed in such a way that the cross-section head width / thickness, body height / thickness and diameter / wall thickness ratios do not exceed the limit values given in the TBEC (see Table 2). 


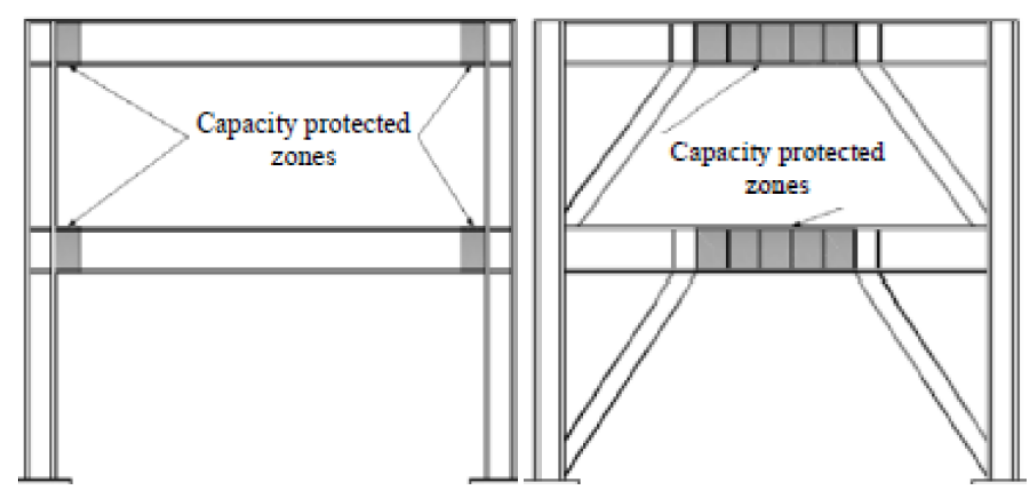

a) moment resisting frame

b) eccentrical braced frame

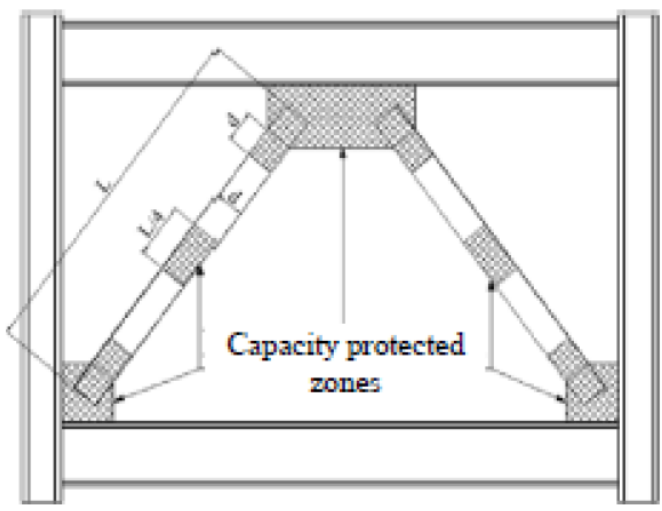

c) central braced frame

Figure 1. Capacity protected zones of different steel frame types (TBEC, 2019).

Table 1. Permissible building height classes, bearing system behaviour and strength excess coefficients of steel structure structural systems according to TBEC (TBEC, 2019)

\begin{tabular}{|l|c|c|c|}
\hline \multicolumn{1}{|c|}{ Steel Building Structural Systems } & R & D & BYS \\
\hline $\begin{array}{l}\text { Structural systems of high ductility level } \\
\text { 1) Buildings where all earthquake effects are carried with moment-transmitting steel frames }\end{array}$ & 8 & 3 & BYS $\geq 3$ \\
\hline $\begin{array}{l}\text { 2) Buildings where all earthquake effects are met by external central or anti-buckling central } \\
\text { braced steel frames }\end{array}$ & 8 & 2.5 & BYS $\geq 2$ \\
\hline 3) Buildings where all earthquake effects are met by central steel braced frames & 5 & 2 & BYS $\geq 4$ \\
\hline $\begin{array}{l}\text { 4) Buildings where the effects of earthquakes are met by moment-transferring steel frames, } \\
\text { external central with a high level of ductility, or centrally braced steel frames that are prevented } \\
\text { from buckling, or reinforced concrete walls with tie beams (hollow) }\end{array}$ & 8 & 3 & BYS $\geq 2$ \\
\hline $\begin{array}{l}\text { 5) Buildings where the effects of earthquakes are met by moment-transferring steel frames and } \\
\text { centrally braced steel frames with high ductility level or hollow-free reinforced concrete walls }\end{array}$ & 6 & 2.5 & BYS $\geq 2$ \\
\hline $\begin{array}{l}\text { 6) Single storey buildings where all earthquake effects are met by steel columns with hinged } \\
\text { connections at the roof level and not exceeding 12 m }\end{array}$ & 4 & 4 & - \\
\hline $\begin{array}{l}\text { Ductility level mixed (hybrid) systems } \\
\text { 1) Buildings where the effects of earthquakes are met by moment-transferring steel frames with } \\
\text { ductility level limited, external central with a ductility level high, or centrally braced steel frames } \\
\text { that are prevented from buckling, or reinforced concrete walls with tie beams with ductility level } \\
\text { high }\end{array}$ & 6 & 2.5 & BYS $\geq 4$ \\
\hline $\begin{array}{l}\text { 2) Buildings where the effects of earthquakes are met by moment-transferring steel frames with } \\
\text { limited ductility level and central braced steel frames with high ductility level or hollow-free } \\
\text { reinforced concrete walls with high ductility level }\end{array}$ & 5 & 2 & BYS $\geq 4$ \\
\hline $\begin{array}{l}\text { Ductility level hybrid structural systems } \\
\text { 1) Buildings where all earthquake effects are met by moment-transferring steel frames }\end{array}$ & 4 & 2.5 & BYS $\geq 7$ \\
\hline $\begin{array}{l}\text { 2) Buildings where all earthquake effects are met by central braced steel frames } \\
\text { 3) Buildings where the effects of earthquakes are met together by moment-transferring steel } \\
\text { frames and central braced steel frames }\end{array}$ & 4 & 2 & BYS $\geq 7$ \\
\hline
\end{tabular}


Table 2. Cross-section conditions of steel construction elements according to TBEC (TBEC, 2019)

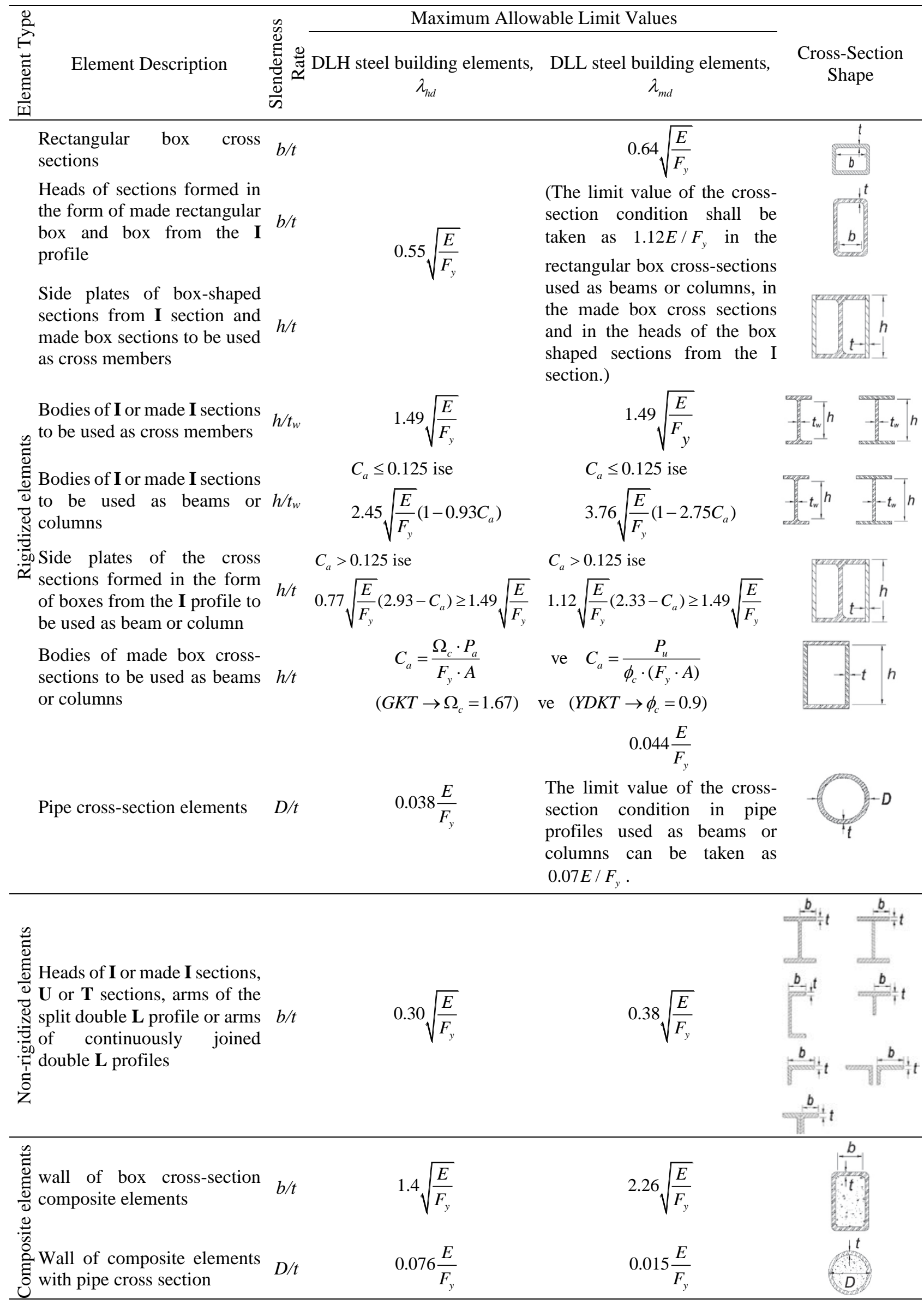


2.1. Design principles of external central steel braced frames according to TBEC

External central steel braced frame systems; it can be designed as diagonal external braced, $\mathrm{V}$ external braced and $\Lambda$ external braced systems (see Figure 2). According to TBEC, the head width / thickness, body height / thickness and diameter / thickness ratios in columns, beams and braced members of the said frames should not exceed the $\lambda_{\text {hd }}$ limit values given in Table 2 . The design principles concerning dimensioning the external central steel braced frames are summarized below.

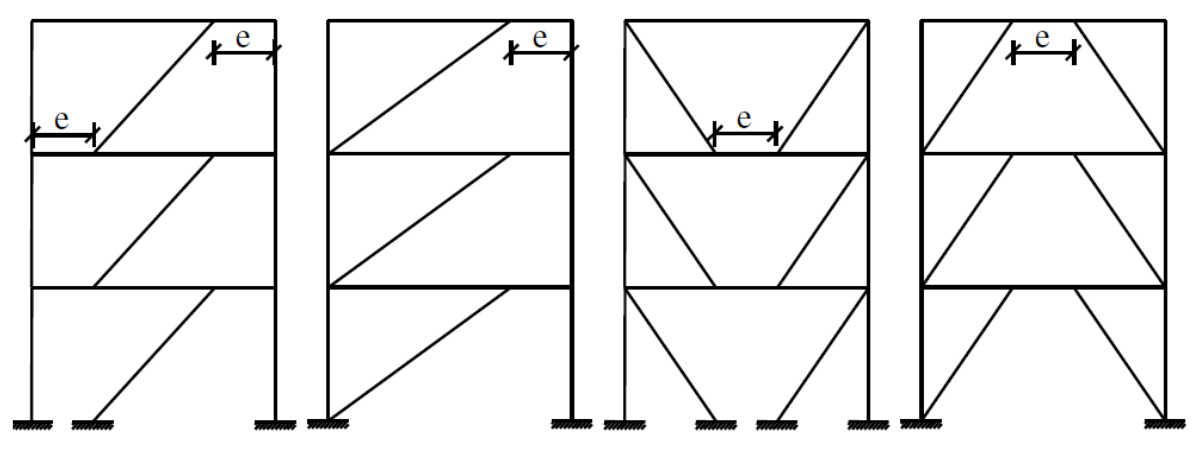

Figure 2. External central steel braced systems (TBEC, 2019).

According to TBDY, bond (tie) beams must meet the following conditions. According to this,

1) In DLH external central steel braced frames, at least one of the cross members must have tie beam at the end and tie beams must be dimensioned according to the calculated internal forces (bending moment, axial force and shear force), taking into account the load combinations including earthquake effects.

2) The shear force design strength of the tie beam, as stated in equation (1), the smaller of the yield limit states under the effect of the shear force in the body and the bending moment of the section should be taken as the shear force strength. It should be noted here that for both boundary cases it will be taken as $V_{n} / \Omega_{v}\left(G K T\right.$ için $\left.\Omega_{v}=1.67\right)$ or

$\phi_{v} \cdot V_{n}\left(Y D K T\right.$ için $\left.\phi_{v}=0.90\right)$.

$V_{n}=\min \left(V_{p} ; 2 M_{p} / e\right)$

The following expressions will be used for the $V_{p}$ and $M_{p}$ expressions in this formula.

$\frac{P_{r}}{P_{y}} \leq 0.15$ for $\quad V_{p}=0.6 * F_{y} * A_{w} \quad$ and $\quad M_{p}=F_{y} * W_{p}$

$\frac{P_{r}}{P_{y}}>0.15$ for $V_{p}=0.6 * F_{y} * A_{w} * \sqrt{1-\left(\frac{P_{r}}{P_{y}}\right)^{2}} \quad$ and $\quad M_{p}=F_{y} * W_{p} *\left(\frac{1-\left(P_{r} / P_{y}\right)}{0.85}\right)$

3) The body plate of the tie beams should be one piece and there should not be reinforcement plates in the plane of the body. In addition, it is not allowed to make a gap in the body plate.

4) The tie beams should be of broad headed rolling mill I profile or made I cross-section. In the case of using tie beam with made cross-section, head and body plate joints should be provided with full penetration butt welding.

5) Depending on the relative story $\operatorname{drift}\left(\Delta_{\mathrm{i}}\right)$ of $\boldsymbol{i}$. story located the bond beam,
$\theta_{p}=\frac{R \cdot \Delta_{i}}{I \cdot h_{i}}$

Due to angle of the relative storey drift found by Eq. (4), The bond beam rotation angle $\left(\gamma_{p}\right)$ formed between the bond beam and the story beam on the extension of this beam should not exceed the following limit values (see Figure 3).

6) 0.08 radians if the bond beam length is less than or equal to $1.6 M_{p} / V_{p}$ 
7) 0.02 radians if the bond beam length is greater than or equal to $2.6 M_{p} / V_{p}$

In the equations given above, $A_{w}\left(d \cdot t_{w}\right)$ shows the body area calculated with the entire cross-section height, $e$ shows the eccentricity in truss joints, $F_{y}$ shows the characteristic yield stress of the structural steel, I shows the structural importance coefficient, $P_{r}$ shows the required axial force

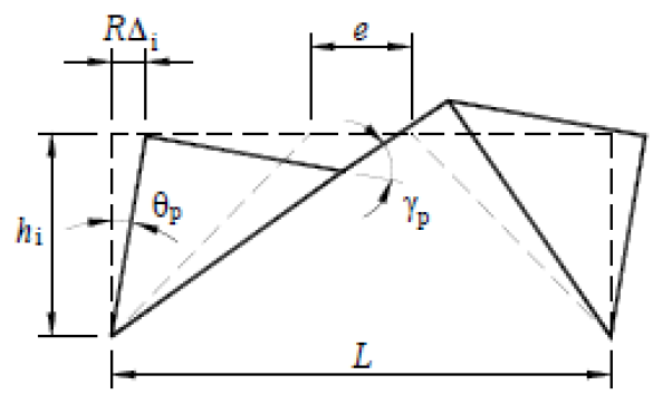

$$
\gamma_{\mathrm{p}}=\frac{L}{e} \theta_{\mathrm{p}}
$$

strength, $P_{y}$ shows the axial force strength at the yield limit state, $R$ shows bearing system behaviour coefficient, $R_{y}$ shows the ratio of the material's possible yield stress to the characteristic yield stress, and $W_{p}$ shows the plastic strength moment relative to the bending axis. It should also be stated that if the length of the tie beam is between these two limit values, it would be appropriate to make a linear proportioning.

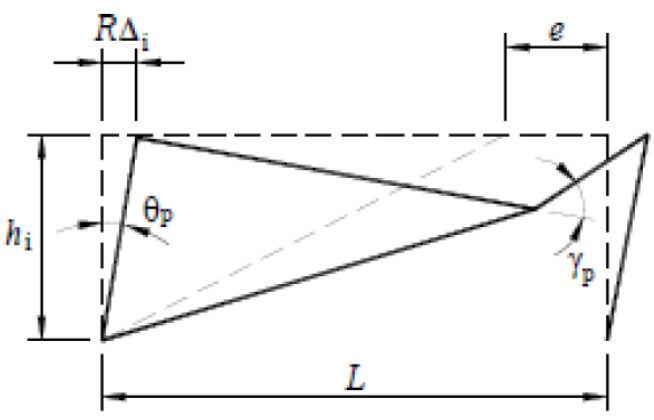

$$
\gamma_{\mathrm{p}}=\frac{L}{e} \theta_{\mathrm{p}}
$$

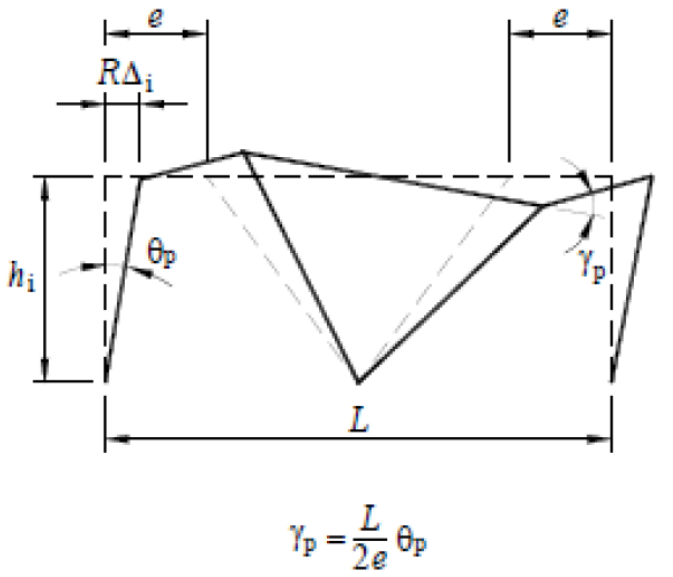

Figure 3. Angles of rotation of tie beams (TBEC, 2019).

According to TBEC, the design of beams, columns and braced must also provide the following conditions. According to this,

1) The loading that causes plasticization of the bond beam will be increased by the design magnification coefficient defined as $V_{n} / V_{E}$, including the design shear force $\left(V_{E}\right)$ and $V_{n}=\min \left(V_{p} ; 2 M_{p} / e\right) \quad$ resulting from earthquake effects in load combinations.

2) In determining the strength of the braced, earthquake effects on load combinations will be increased by $1.25 R_{y}$ the load that causes the tie beam to plasticize.
3) In determining the strength of the frame beams other than the tie beam; the earthquake effects in load combinations will be increased by $1.1 R_{y}$ the load that causes plasticization of the tie beam, in the case where the beams work as a composite with reinforced concrete slabs, and in the other case by a times of $1.25 R_{y}$.

4) In determining the required strength of the columns; earthquake effects in load combinations will be increased by $1.1 R_{y}$ times the load that causes plasticization of the tie beam. 
5) The length of the bond beam connecting to the column must provide the $e \leq 1.6 * M_{p} / V_{p}$ condition.

6) When the beam is connected hinged to the column, the connection detail should be created in a way to provide a rotation angle of at least 0.025 radians. For this connection detail, one of the column-beam connection details given in

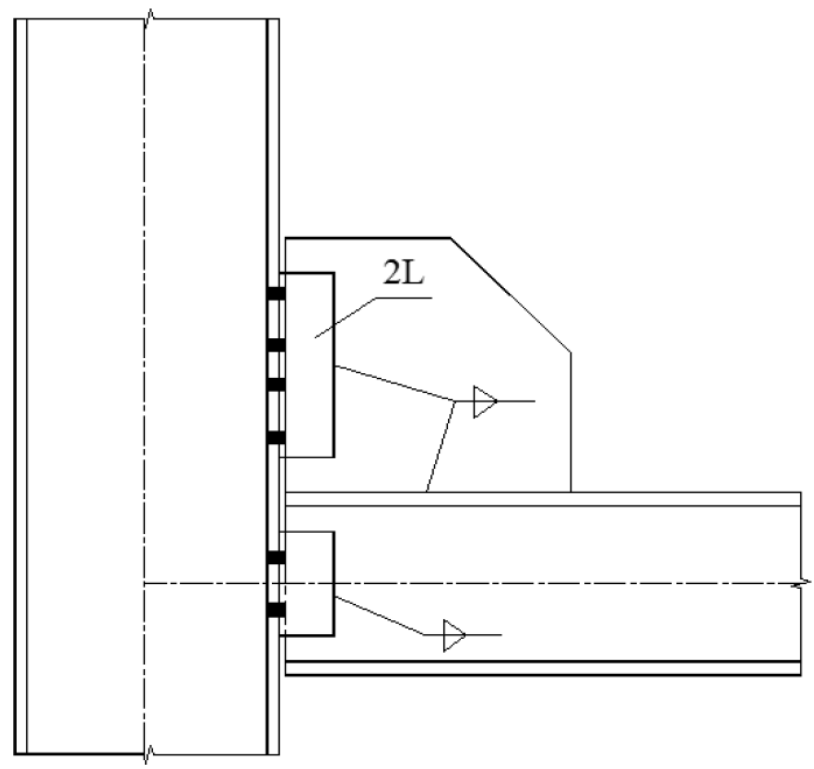

a) Hinged connection
Figure 4 or analytically proven that this condition is met can be used.

7) Braced connections must have sufficient rotational capacity. Sufficient rotational capacity here will be provided by forming suitable connections that allow plastic rotation in the node plate or connection plate to be used at the end joints of the cross members.

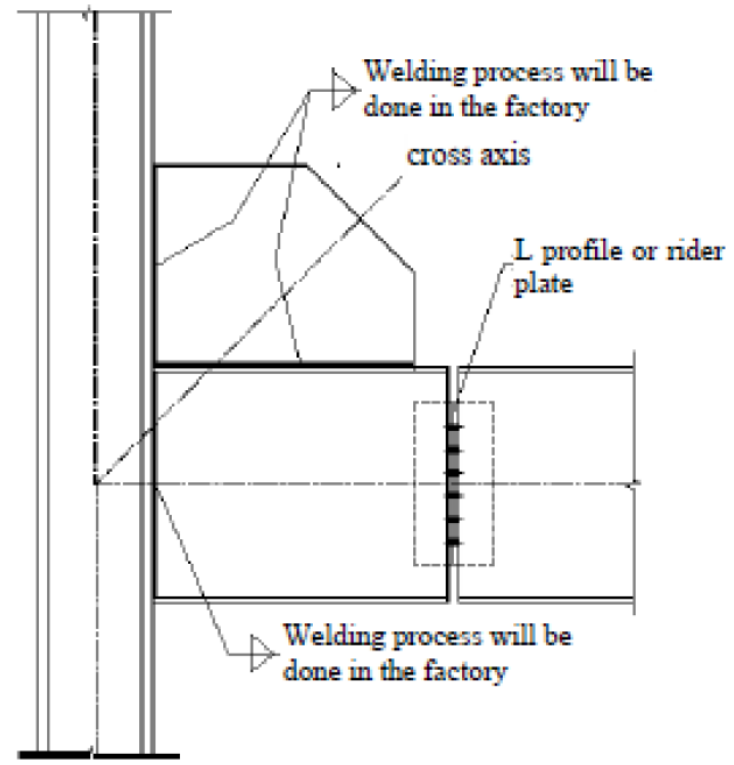

b) rigid connection

Figure 4. Hinged and rigid connection detail according to TBEC (TBEC, 2019).

\section{Design principles according to the regulation on design, calculation, and construction of steel structures}

According to this regulation, the designs of steel structure structural elements and their connections can be made with load and strength factors or safety factors. The loads stipulated in the design of the building elements and their combinations are calculated with the load combinations given in the said regulation (ÇYTHYDE, 2018).

\subsection{Boundary situations}

With the prescribed load combinations, the design of a steel structure is made in a way that the strength and usability does not exceed the limit state. Of these,

Strength limit state; while defining the regional and / or total collapse formation due to insufficient strength and stability throughout the life of the structure,

Usability limit state; It is defined as excessive displacements that prevent the expected functions from the structure.

\subsection{Stability analysis}

According to the regulations on the design, calculation, and construction principles of steel structures, it is recommended to calculate the stability analysis of steel structures according to the $2^{\text {nd }}$ order theory (ÇYTHYDE, 2018). $2^{\text {nd }}$ order theory is a method of structural analysis in which the effect of geometry changes in elements and system-wide on equilibrium equations is considered.

The main factors affecting the stability of steel structures,

1) The bending, shear and axial deformation of the structural elements that make up the steel structure structural system, as well as all other deformations that are effective in the displacement of the structure system (such as column-beam connection, etc.), 
2) $2^{\text {nd }}$ order effects on deformation of steel structure elements and structure displacement,

3) Geometric frontal imperfections,

4) Nonlinear deformations are uncertainties in strength and stiffness.

\subsection{Design of connections}

According to the regulation on the design, calculation, and construction principles of steel structures, connections can be formed in two ways: hinged and moment-transferring connections. Bending moment is at or near zero value in hinged joints. However, in these combinations, relative rotation between components is allowed.

Moment-transferring connections are divided into two as fully rigid and semi-rigid (elastic). In these connections, the bending moment values are different from zero, whereas the relative rotational movement between the joined elements is zero or limited depending on whether the connection is fully rigid or semi-rigid.

\subsection{Design for structural integrity}

Conditions to be met for structural integrity will be evaluated independently from other strength conditions. The following conditions must be provided for structural integrity.

1) The characteristic tensile strength of the column connections must be equal to or greater than the axial force calculated by the G+Q load combination.

2) The tensile strength of the beam end connections must be equal to $2 / 3$ of the required shear strength if load and strength factors is made or to the required shear strength if safety factors is made. However, this value must be required at least $50 \mathrm{kN}$.

3) It is recommended that the characteristic tensile strength of the end connections of the elements that ensure the stability of the columns be taken at least equal to $1 \%$ of the value calculated by $2 / 3$ of the required axial strength of the column determined according to the load and strength factors method and equal to $1 \%$ of the required axial strength of the column determined according to the safety factors method.

According to this regulation, the conditions regarding the detailed design of the connection and connection elements can be seen in the said regulation (ÇYTHYDE, 2018).

\section{Examination of the behaviour of building models}

In this article, 7 steel structure models with different external central steel braces in different shapes and locations with the same story area and dimensions were created and their structural analyses were carried out with the Sta-Steel program. The steel structure models considered were designed as 3-span, 5-storey and column footing system (see Figure 5). The height of each story of the building models created is $3 \mathrm{~m}$ and the axle spans is $6 \mathrm{~m}$. The dimensions of the structural elements (columns, beams and braced members) of the mentioned models are given in Table 3 . In addition, it is accepted that S335 steel material is used in all structural systems of steel structure models and secondary intermediate beams are placed at $1.5 \mathrm{~m}$ intervals (Y1lmaz, 2020). On the other hand, the yield stress of the bolts in the connections, joints and foundation connections of structural elements is $F_{y b}=640 \mathrm{MPa}$. In addition, it is accepted that the modulus of elasticity of the steel material used in building models is $E_{s}=200000 \mathrm{~N} / \mathrm{mm}^{2}$.

Table 3. Profiles used in structural system elements of steel building models

\begin{tabular}{lcc}
\hline \multirow{2}{*}{ Structural system elements } & \multicolumn{2}{c}{ Profiles } \\
\cline { 2 - 3 } & DLH & DLL \\
\hline Columns & He340 B & He340 B \\
Main beams & IPE300 & IPE330 \\
Intermediate beams & IPE220 & IPE220 \\
Cross elements & R120x10 & R120x10 \\
\hline
\end{tabular}




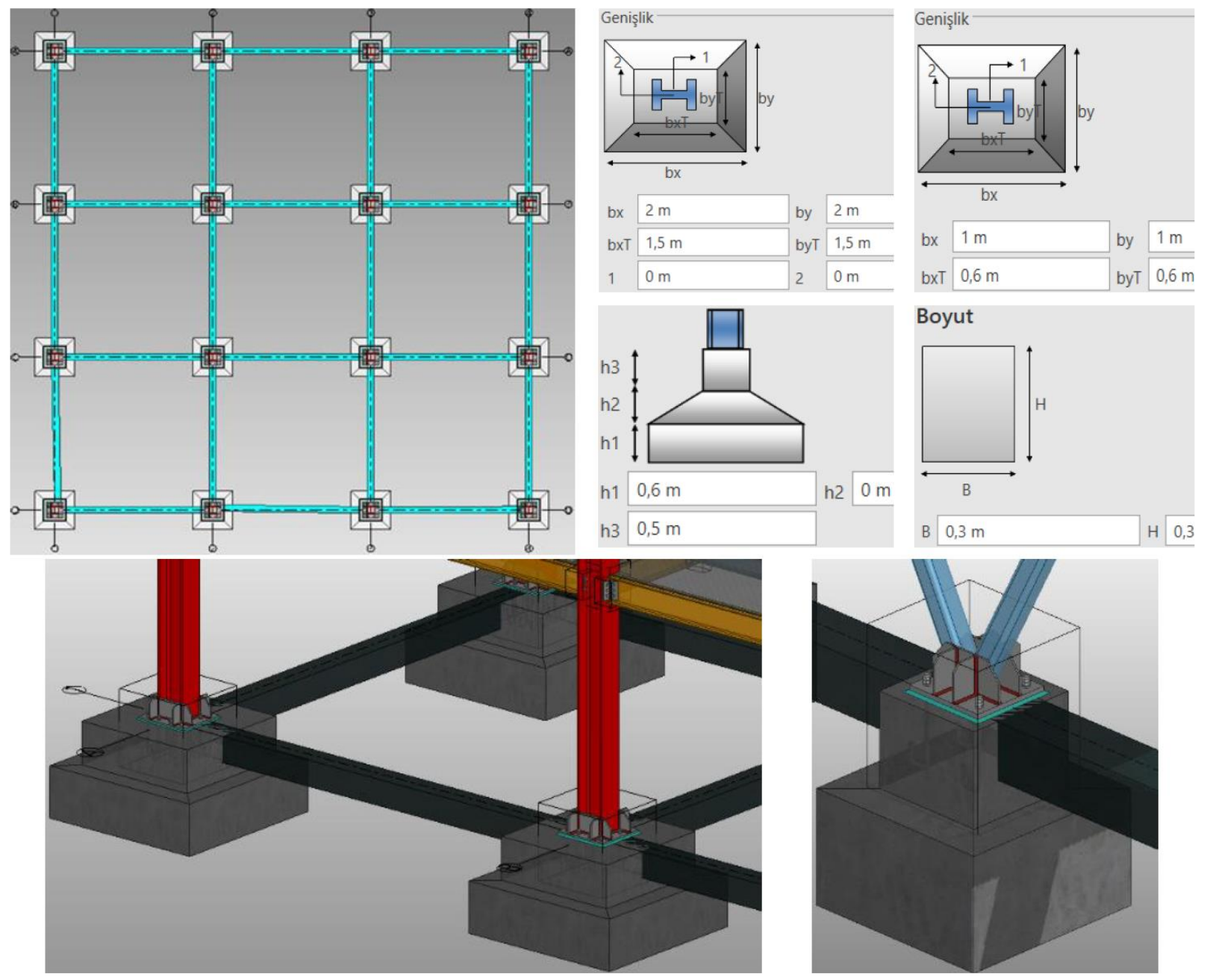

Figure 5. Views from the foundation plan and foundation detail-dimensions of building models.

Other features of the selected steel structure models are given below (Y1lmaz, 2020).

In Model 1, in the moment-transferring frame, it is accepted that all column and beam dimensions are as in Table 3 (see Figure 6a).

In Model 2, all column and beam dimensions are considered as in Table 3. Also, in this model, outer axles are formed from $80 \mathrm{~cm}$ long bond beams and outer center $\mathrm{V}$ steel crosses using R120x10 box profile (see Figure 6b).

In Model 3, all column and beam dimensions are considered as in Table 3. Also, in this model, eccentric steel diagonal braces were formed by using R120x 10 box profiles on the outer axles (see Figure 6c).

In Model 4, it is accepted that all column and beam dimensions are as in Table 3. Also in this model, the outer axles are formed from $80 \mathrm{~cm}$ long tie beams and external central $\Lambda$ steel crosses using R120x10 box profile (see Figure $6 d)$.
In Model 5, it is accepted that all column and beam dimensions are as in Table 3 . In addition, in this model, the outer axles are formed from $1.5 \mathrm{~m}$ long tie beams and external central $\mathrm{V}$ steel braces using R120x10 box profile (see Figure $6 e)$.

In Model 6, it is accepted that all column and beam dimensions are as in Table 3. Also, in this model, the outer axles are formed from $80 \mathrm{~cm}$ long tie beams and external central $\Lambda$ steel crosses using R120x10 box profile from $35 \mathrm{~cm}$ above from the column-beam connection center (see Figure 6f).

In Model 7, it is accepted that all column and beam dimensions are as in Table 3 . In addition, in this model, the outer axles were formed from $1.5 \mathrm{~m}$ long tie beams and external central steel diagonal braces using R120x 10 box profile in 35 $\mathrm{cm}$ above from the column-beam connection center (see Figure 6g). 

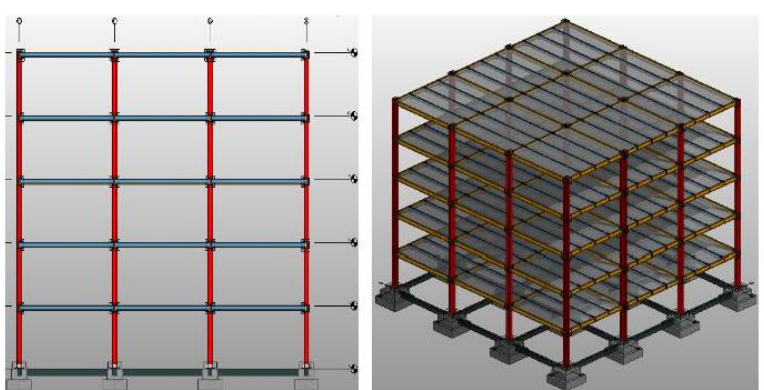

a) model 1
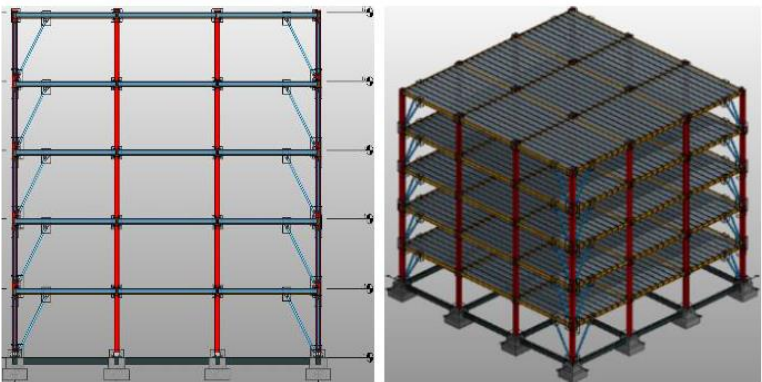

c) model 3
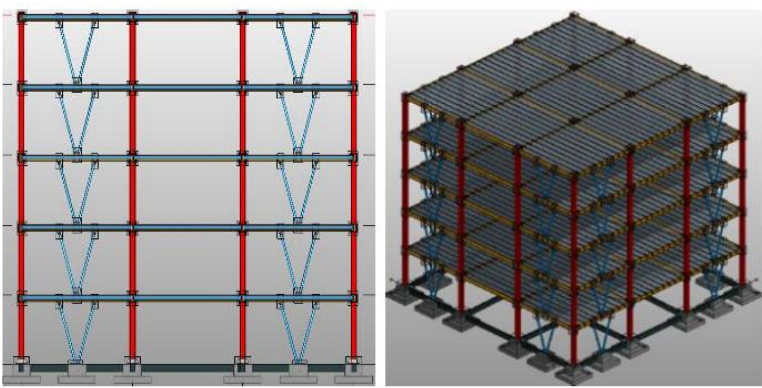

e) model 5

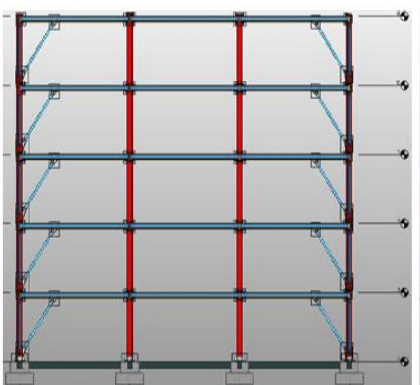

g) $\operatorname{model} 7$
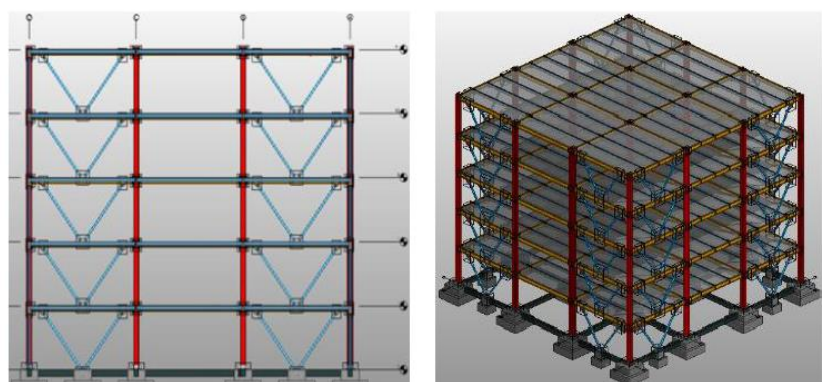

b) model 2
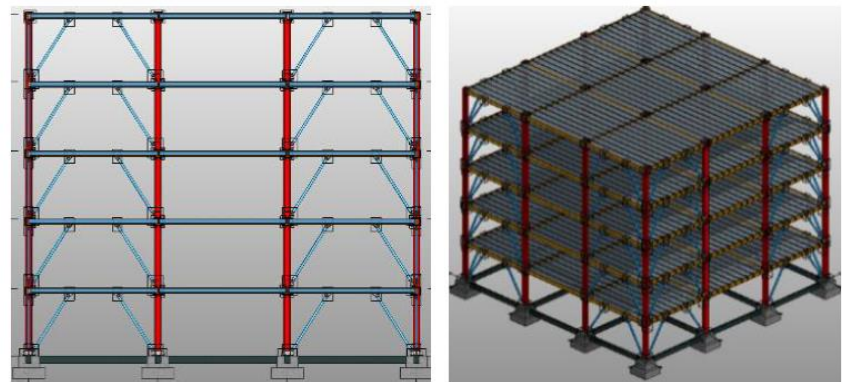

d) model 4
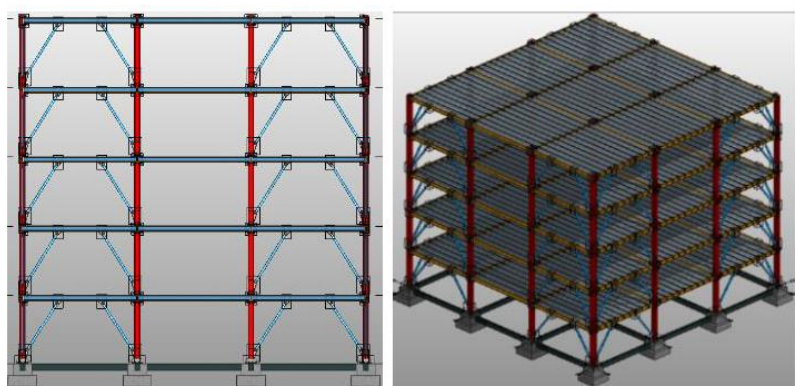

f) model 6

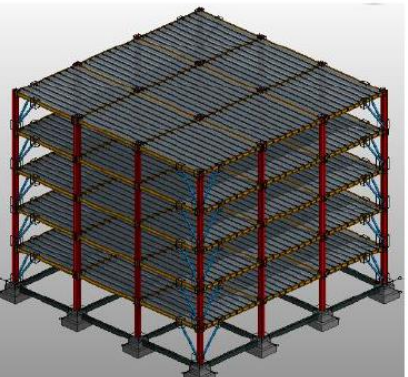

Figure 6. Cross-section and 5-story view of steel building models.

Here, it will be useful to state that model 1 is the reference model, and that other building models are connected to the columns from different points depending on the length $(e)$ of the tie beams, and external central steel brace types are created. The details of the tie beams of the steel structure models are summarized in Table 4.

Table 4. Information's on the connection details of building models

\begin{tabular}{|c|c|c|c|}
\hline Models & Cross elements & Bond (tie) beam lengths (m) & Column connection of cross members \\
\hline model 1 & 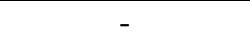 & 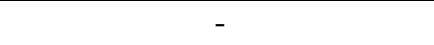 & - \\
\hline model 2 & $\mathrm{R} 120 \times 10$ & 0.8 & From the center \\
\hline model 3 & $\mathrm{R} 120 \times 10$ & 1.5 & From the center \\
\hline model 4 & $\mathrm{R} 120 \times 10$ & 0.8 & From the center \\
\hline model 5 & $\mathrm{R} 120 \times 10$ & 1.5 & From the center \\
\hline model 6 & $\mathrm{R} 120 \times 10$ & 0.8 & From $0.35 \mathrm{~m}$ above \\
\hline model 7 & $\mathrm{R} 120 \times 10$ & 1.5 & From $0.35 \mathrm{~m}$ above \\
\hline
\end{tabular}


The story areas of the steel structure models considered are equal, $\mathrm{ZC}$ is the local ground class, said structure models will be built in the neighbourhood of Karabük Province and accordingly Earthquake Map of Turkey are considered to be the design parameters related to 41.21329 latitude and 32.63601longitude. (Y1lmaz,
2020). In addition, TS-498 Regulation on Calculation Values of the Loads to be Taken in the Sizing of Building Elements is used in the calculation of the loads affecting the said models (TS-498, 1997). Other design parameters considered in structural analysis are given in Table 5.

Table 5. Other design parameters considered in structural analyses.

\begin{tabular}{|c|c|c|}
\hline \multicolumn{2}{|l|}{ Building importance coefficient (residence and workplace), $I$} & 1 \\
\hline \multirow{2}{*}{ Structural system behaviour coefficients, $\left(\mathrm{R}_{\mathrm{x}}\right.$ ve $\left.\mathrm{R}_{\mathrm{y}}\right)$} & Ductility level high & 8 \\
\hline & Ductility level limited & 4 \\
\hline \multicolumn{2}{|l|}{ Live load participation coefficient (residences and workplace) } & 0.30 \\
\hline \multicolumn{2}{|l|}{ Short period map spectral acceleration coefficient, $\left(\mathrm{S}_{\mathrm{s}}\right)$} & 0.722 \\
\hline \multicolumn{2}{|l|}{ Map spectral acceleration coefficient for $1 \mathrm{~s}$ period, $\left(\mathrm{S}_{1}\right)$} & 0.2337 \\
\hline \multicolumn{2}{|l|}{ Short period design spectral acceleration coefficient, $\left(S_{\mathrm{ds}}\right)$} & 0.8744 \\
\hline \multicolumn{2}{|l|}{ Design spectral acceleration coefficient for $1 \mathrm{~s}$ period, $\left(\mathrm{S}_{\mathrm{d} 1}\right)$} & 0.351 \\
\hline \multicolumn{2}{|l|}{ Earthquake ground motion level } & DD2 \\
\hline \multicolumn{2}{|l|}{ Earthquake design class } & DTS1 \\
\hline \multirow{2}{*}{ Strength excess coefficients $\left(D_{x}\right.$ ve $\left.D_{y}\right)$} & Ductility level high & 3 \\
\hline & Ductility level limited & 2.5 \\
\hline \multirow{2}{*}{\multicolumn{2}{|c|}{$\begin{array}{l}\text { Foundation soil bearing capacity for ZC local soil class }\left(\mathrm{kN} / \mathrm{m}^{2}\right) \\
\text { Foundation bedding coefficient for ZC local ground class }\left(\mathrm{kN} / \mathrm{m}^{3}\right)\end{array}$}} & 150 \\
\hline & & 10000 \\
\hline \multicolumn{2}{|l|}{ Modal analysis min load ratio, $(\beta)$} & 0.90 \\
\hline \multicolumn{2}{|l|}{ Earthquake eccentricity } & 0.05 \\
\hline \multicolumn{2}{|l|}{ Horizontal elastic design acceleration spectrum corner period, $\mathrm{T}_{\mathrm{A}}(s)$} & 0.08021 \\
\hline \multicolumn{2}{|l|}{ Horizontal elastic design acceleration spectrum corner period, $\mathrm{T}_{\mathrm{B}}(s)$} & 0.40103 \\
\hline \multicolumn{2}{|c|}{ Transition period to constant displacement in the spectrum of horizontal elastic design, $\mathrm{T}_{\mathrm{L}}(s)$} & 6 \\
\hline \multicolumn{2}{|c|}{ Snow load $\left(k N / m^{2}\right)$} & 0.75 \\
\hline \multicolumn{2}{|l|}{ Moving load $\left(\mathrm{kN} / \mathrm{m}^{2}\right)$} & 2 \\
\hline \multirow{3}{*}{$\begin{array}{l}\text { Wind load }\left(k N / m^{2}\right) \\
\text { Building height }(m)\end{array}$} & up to $8 \mathrm{~m}$ high & 0.5 \\
\hline & up to $20 \mathrm{~m}$ high & 0.8 \\
\hline & & 15 \\
\hline
\end{tabular}

\section{Findings and evaluations obtained from structural analyses}

As a result of the structural analyses performed with the Sta-Steel program of the DLH steel structure models with different external central cross members considered in this study, the views of the building models with insufficient structural elements are given in Figure 7. It is seen from these figures that the cross-section some of the profiles used in the intermediate beams of model 2 and model 5 are insufficient. This situation reveals that the models in question are insecure in their current state, and therefore, the required to increase the cross-sectional dimensions of the insufficient structural elements of these models in order to ensure sufficient safety. As such, sufficient safety has been provided by using IPE240 profile instead of IPE220 in intermediate beams, which are insufficient of these models. In addition, in model 5 , it is seen that some foundations where the cross members are supported in the middle of the span are insufficient. The inadequate foundation dimensions of Model 5 have been made safe by selecting 1 x $1.5 \mathrm{~m}$.

In this article, it is aimed to compare the performances of steel structure systems with different external central steel braced. For this purpose, the nodal point at which the maximum displacement values occur in all building models have been taken into consideration for comparison (see Figure 8). 


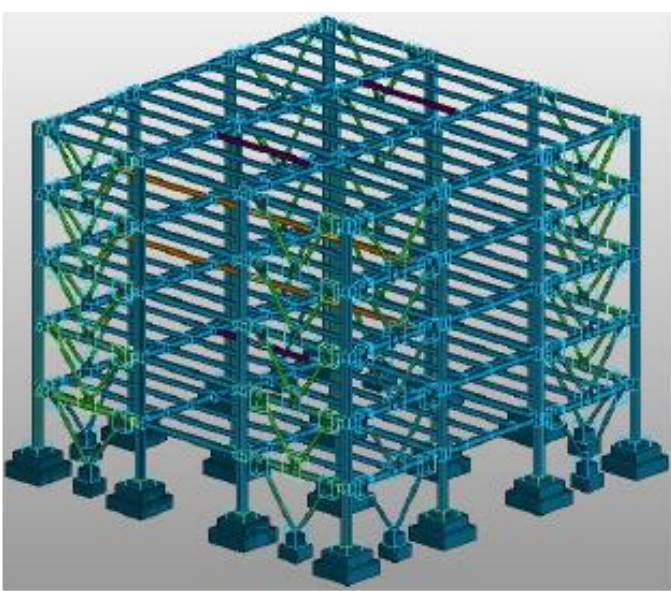

a) model 2

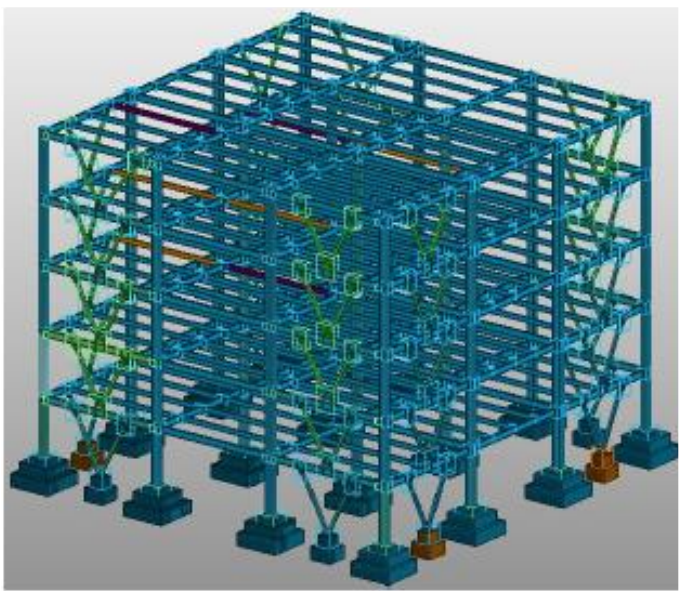

b) model 5

Figure 7. Views from insufficient structural elements of model 2 and model 5 for dead loads.

According to TBEC, different types of combinations are used to form the nodal point of steel structures (see Figure 8). Accordingly, both DLH and DLL are modelled in a way that the frames with different external central steel braces

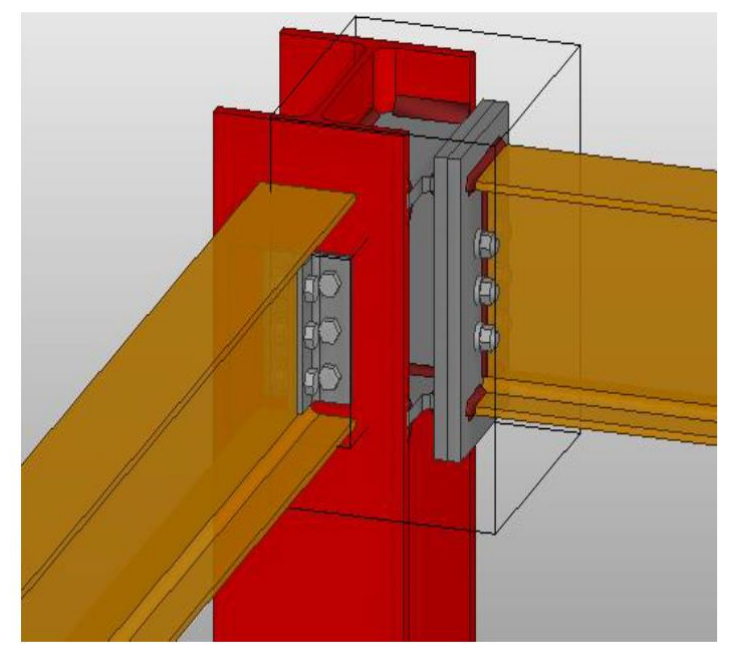

a) Combination detail of hinged and semi-rigid node point are hinged with their strong axes and their weak axes are semi-rigid (see Figure 9a). Because, as a result of the structural analysis performed, the semi-rigid node joint in DLL frames could not provide sufficient safety (see Figure 9b). For this reason, a node combination providing sufficient security was preferred in both DLH and DLL frames. In summary, the nodal point of the building models with different external central steel cross members are modelled as their strong axes are hinged and their weak axes are semi-rigid (see Figure 9a).

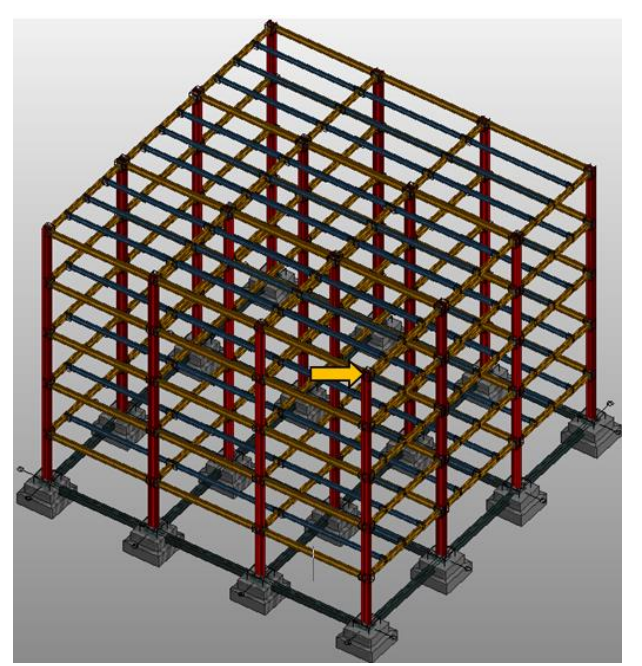

Figure 8. The node point for comparisons

Here, the combination detail of the node point in Figure 8 provides sufficient safety for both DLH and DLL situations, and that the DLL structure models formed with different external central steel cross members, except for model 2 and model 5, It will be appropriate to state that it is used that the IPE 330 profile instead of IPE300 to ensure sufficient safety in the main beams.

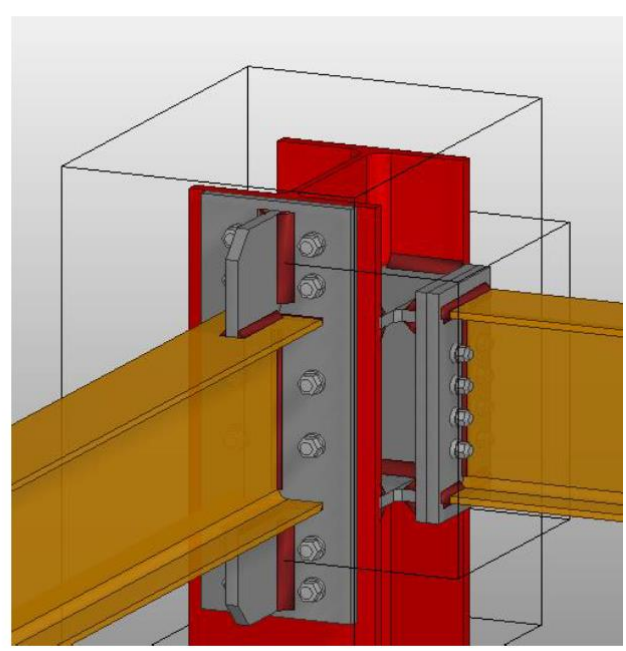

b) Combination detail of semi-rigid node point

Figure 9. Different nodal point combination details used in the creation of the models. 
The displacement values of the selected node point in the $\mathrm{x}$ direction as a result of the structural analyses performed for the earthquake effect in the $\mathrm{x}$ direction of the different external central steel braced steel structure models of DLH and DLL are given in Table 6. From this table, it is seen that the displacement values of the DLL external central steel braced steel structure models are greater than the DLH external central steel braced steel structure models and while the value of the largest displacement value for DLL structure models is obtained from model 7, the lowest displacement value is obtained from model 2 . In addition, it is seen that the displacement values of both DLH and DLL structure models with single cross member are greater than the other building models considered. These findings reveal that the external central steel braced steel structure models significantly reduce the maximum displacement values compared to the reference model, model 1 , as expected, except for model 3 and model 7.

Table 6. Maximum displacement values of selected nodal point for earthquake effect in $\mathrm{x}$ direction of building models with SDY and SDS different external central steel braced

\begin{tabular}{|c|c|c|c|c|c|c|c|c|}
\hline & & model 1 & model 2 & model 3 & model 4 & model 5 & model 6 & model 7 \\
\hline Maximum displacement & DLH & 8.874 & 1.769 & 10.037 & 1.898 & 3.341 & 2.04 & 10.028 \\
\hline values (mm) & DLL & 21.70 & 2.024 & 19.178 & 3.240 & 6.911 & 3.59 & 21.854 \\
\hline
\end{tabular}

The maximum base shear forces values obtained in the $\mathrm{x}$ and $\mathrm{y}$ directions from the structural analyses made with the Sta-Steel program using modal combination and equivalent earthquake load methods of DLH and DLL different external central steel braced structure models are given in Table 7. From this table, it is seen that the base shear strength values of DLL external central steel braced steel structure models in both $\mathrm{x}$ and $\mathrm{y}$ direction are greater than the DLH external central steel braced steel structure models. On the other hand, the base shear force values obtained by the equivalent earthquake load method (EELM) in both $\mathrm{x}$ and $\mathrm{y}$ directions of the DLH and DLL external central steel braced steel structure models are higher than those obtained by the modal combination method (MCM). In addition, it seems that DLL steel structure models, the maximum base shear values according to the equivalent earthquake load method of is obtained from model 5 in the $x$ direction and model 4 in the $y$ direction, and according to the mode combination method are obtained from model 2 in the $\mathrm{x}$ direction and model 1 in the y direction. These findings obtained from the structural analyses show that the DLL external central steel braced structure models are subjected to greater shear forces than the DLH external central steel braced structure models.

Table 7. Maximum base shear force values of building models with DLH and DLL different external central steel braced

\begin{tabular}{|c|c|c|c|c|c|c|c|c|}
\hline \multirow{4}{*}{ models } & \multicolumn{8}{|c|}{ Maximum base shear force values $(\mathrm{kN})$} \\
\hline & \multicolumn{4}{|c|}{ DLH } & \multicolumn{4}{|c|}{ DLL } \\
\hline & \multicolumn{2}{|c|}{$\begin{array}{l}\text { Earthquake effect in the } \mathrm{x} \\
\text { direction }\end{array}$} & \multicolumn{2}{|c|}{$\begin{array}{c}\text { Earthquake effect in the y } \\
\text { direction }\end{array}$} & \multicolumn{2}{|c|}{$\begin{array}{l}\text { Earthquake effect in the } \mathrm{x} \\
\text { direction }\end{array}$} & \multicolumn{2}{|c|}{$\begin{array}{l}\text { Earthquake effect in the } y \\
\text { direction }\end{array}$} \\
\hline & MCM & EELM & $\mathrm{MCM}$ & EELM & MCM & EELM & $\mathrm{MCM}$ & EELM \\
\hline model 1 & 121.17 & 212.03 & 181.94 & 214.28 & 217.68 & 281.08 & 432.42 & 503.69 \\
\hline model 2 & 107.59 & 221.01 & 171.87 & 220.68 & 241.46 & 289 & 406.18 & 500.68 \\
\hline model 3 & 98.887 & 214.47 & 173.54 & 216.18 & 188.65 & 339.37 & 398.52 & 504.16 \\
\hline model 4 & 104.86 & 214.63 & 167.38 & 216.77 & 178.88 & 340.28 & 385.69 & 505.73 \\
\hline model 5 & 103.43 & 219.58 & 174.34 & 219.89 & 171.38 & 350.92 & 388.24 & 493.85 \\
\hline model 6 & 104.22 & 214.48 & 168.2 & 216.62 & 174.49 & 339.89 & 387.22 & 505.28 \\
\hline model 7 & 98.93 & 214.64 & 175.57 & 216.29 & 165.41 & 339.56 & 403.67 & 504.58 \\
\hline
\end{tabular}

The maximum displacement distributions obtained at the storey levels along the building height from the structural analyses performed by DLH and DLL for the earthquake effect of the building models created with different external central steel braced members considered are given in Figure 10. From this figure, it is seen that the maximum displacement distributions at the storey levels of the DLL external central steel braced structure models are larger than the DLH external central steel braced structure models and the displacement distributions obtained from the model 1 are generally larger. These findings reveal that both DLH and DLL external central steel braced 
structure models significantly reduce the maximum displacement values compared to model 1 , and the DLH external central steel braced structure models will perform better than the DLL external central steel braced structure models.

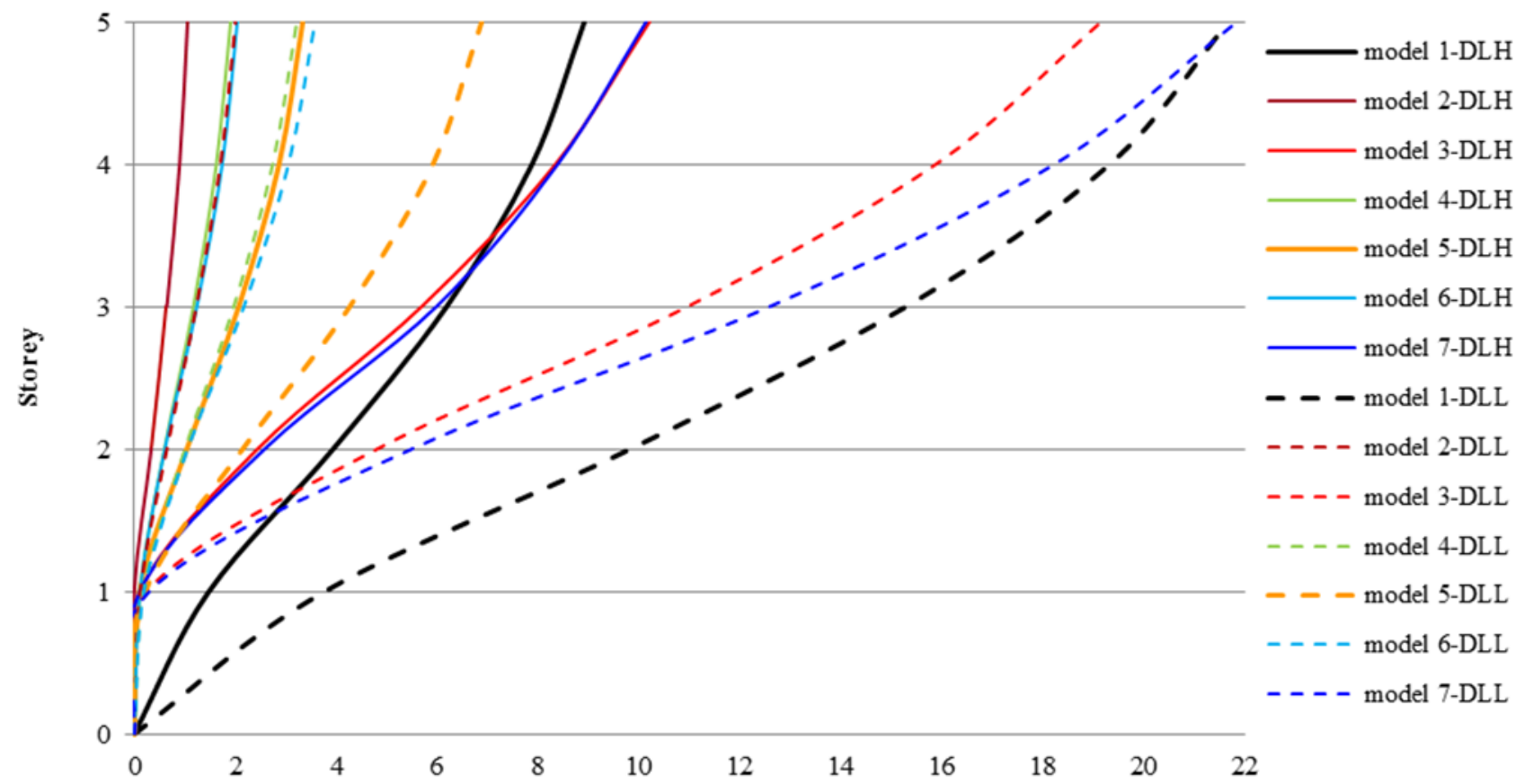

Displacement (mm)

Figure 10. Maximum displacement values in the storey levels under the earthquake effect of building models with DLH and DLL different external central steel braced

Table 8. Structural element cross-section dimensions and tie beam lengths of DLH external central $\Lambda$ and V steel braced structure models

Model a


The effect of different tie beam lengths on the behaviour of the considered DLH external central $\Lambda$ and $\mathrm{V}$ steel braced structure models (model 2 and model 4) was examined (see Table 8). The maximum displacement and rotation values at the tie beam braced member combination node point, from the structural analyses performed for the earthquake effect in the $\mathrm{x}$ direction with the StaSteel program of the DLH steel structure models are given in Table 9. From this table, it is seen that the displacement and rotation values of the $\mathrm{V}$ steel braced structure model increase with the increase in the length of the tie beam compared to the $\Lambda$ steel braced structure model. In addition, with the increase of the tie beam length in both $\Lambda$ and $\mathrm{V}$ steel braced structure models, the displacement values at the said node also increase. On the other hand, it is seen that the displacement and rotation values of $\Lambda$ steel braced structure models in short tie beam lengths and $\mathrm{V}$ steel braced structure models in long tie beam lengths are great. These findings reveal that the length of the tie beam significantly changes the displacement and rotation values of both $\Lambda$ and $\mathrm{V}$ steel braced structure models.

Here, it would be appropriate to state that as a result of the structural analyses carried out according to the earthquake in the $\mathrm{x}$ direction, the $\mathrm{V}$ steel braced structure models cannot provide sufficient safety with the element cross-section dimensions given in Table 8, therefore, structural analyses are made by increasing the cross-section dimensions of the intermediate beams (IPE 240) to ensure sufficient safety.

Table 9. The maximum displacement and rotation values at the combination node point of the tie beam and braced member, depending on the length of the tie beams of the DLH external central $\Lambda$ and V braced structure models

\begin{tabular}{|c|c|c|c|c|}
\hline \multirow{2}{*}{ Models } & \multirow{2}{*}{\multicolumn{2}{|c|}{ Tie beam length (mm) }} & \multicolumn{2}{|c|}{ Earthquake effect in the $\mathrm{x}$ direction } \\
\hline & & & Displacement, $\delta_{x}(\mathrm{~mm})$ & Rotation, $\theta_{x}(\mathrm{rad})$ \\
\hline \multirow{2}{*}{ Model a } & \multirow{2}{*}{500} & $\Lambda$ with steel braced & 1.489 & -0.000201 \\
\hline & & $\mathrm{V}$ with steel braced & 1.421 & -0.000132 \\
\hline \multirow{2}{*}{ Model b } & \multirow{2}{*}{800} & $\Lambda$ with steel braced & 1.887 & -0.000162 \\
\hline & & $\mathrm{V}$ with steel braced & 1.854 & -0.000143 \\
\hline \multirow{2}{*}{ Model c } & \multirow{2}{*}{1000} & $\Lambda$ with steel braced & 2.188 & -0.000186 \\
\hline & & $\mathrm{V}$ with steel braced & 2.229 & -0.000146 \\
\hline \multirow{2}{*}{ Model d } & \multirow{2}{*}{1500} & $\Lambda$ with steel braced & 3.056 & -0.000104 \\
\hline & & $\mathrm{V}$ with steel braced & 3.323 & -0.000128 \\
\hline
\end{tabular}

\section{Conclusions and recommendations}

In this article, the effects on their behaviour of the structures in question of DLH and DLL different external central braced types widely used in the design of steel structures in Turkey were comparatively investigated. The main results and recommendation obtained from the structural analyses carried out for this purpose are presented below.

The displacement values of DLH external central steel-braced structural models from the structural analyses are smaller than DLL external central steel-braced-structured models. In addition, the displacement values of the DLH and DLL single cross member steel structure models are higher than the other steel structure models considered in this study. obtained this result shows that the ductility level significantly affects the behaviour of the structure in question.
From the structural analyses, the base shear force values of the DLL external central steel braced structure models are larger than the DLH external central steel braced structure models in both $\mathrm{x}$ and $\mathrm{y}$ directions. This result shows that the DLL external central steel braced structure models are subjected to greater shear forces than the DLH external central steel braced structure models.

The base shear force values obtained by the equivalent earthquake load method in the $\mathrm{x}$ and $y$ directions of the DLH and DLL external central steel braced structure models are greater than those obtained by the modal combination method.

As a result of the structural analyses of DLH and DLL building models for earthquake effect, it is seen that the maximum displacement distribution at the story levels of the DLL external central steel braced structure models is greater than the DLH external central steel 
braced structure models. This result reveals that DLH external central steel braced structure models will perform better than DLL external central steel braced structure models.

As a result of the structural analyses, the displacement and rotation values obtained from the $\mathrm{V}$ steel braced structure model at the tie beam-braced member combination node point are higher than the $\Lambda$ steel braced structure model. In addition, with the increase of the tie beam length in both $\Lambda$ and $\mathrm{V}$ steel braced structure models, the displacement values at the said node point also increase.

Given the findings of this study, in terms of safety and performance of the steel structures in Turkey that to be constructed especially earthquake zones is recommended the prefer of design and construction of steel structures having DLH external central steel braced members.

\section{Acknowledgments}

The license of the Sta-Steel program used in this study was obtained by the Rectorate of Karabük University.

\section{References}

Arıbaş, S., Sancioğlu, S. ve Çarbaş, S. (2019). Dışmerkez V çaprazların çelik bir yapı üzerinde incelenmesi. KMÜ Mühendislik ve Doğa Bilimleri Dergisi, 1(1), 79-97.

Akgönen, A. İ. (2017). Yüksek sünek merkezi çaprazlı çelik çerçevelerin yatay yükler altında davranışının incelenmesi, KSÜ Mühendislik Bilimleri Dergisi, 20(3): 16-23.

Ay, Z. ve Çelik, İ.D. (2012). Dışmerkez çelik çapraz perde bir sistemde bağ kirişi boyunun 2007 Türk Deprem Yönetmeliği açısından incelenmesi, IMO Teknik Dergi, Yazı 372, 5827-5843.

Ay, Z., Çelik, İ.D. ve Kımıllı, N. A. (2010). Çaprazlı çelik çerçevelerin sismik performansı üzerine bazı değerlendirmeler. Erciyes Üniversitesi Fen Bilimleri Enstitüsü Dergisi, 26(1), 7-17.
Bayram, B., Sancıoğlu, S. ve Çarbaş, S. (2019). Çelik bir yapıda dişmerkez diyagonal çaprazların etkisi. KMÜ Mühendislik ve Doğa Bilimleri Dergisi, 1(1), 128-145.

Çavdar, Ö. (2017). Farklı şekilde çapraz elemanlı çelik yapıların dinamik davranışının incelenmesi, Uluslararası Katılımlı 7. Çelik Yapılar Sempozyumu, Gaziantep, 193-203.

Çavdar, Ö. (2019). Determination of the Seismic Performance of Concentrically Braced Steel Structures, International Journal of Science and Engineering Applications, 8(12), 503-508. https://dx.doi.org/10.7753/IJSEA0812.1002

ÇYTHYDE. (2018). Çelik Yapıların Tasarım, Hesap ve Yapımına Dair Esaslar. Çevre ve Şehircilik Bakanlığı. Türkiye.

Gönen, H. (1997). Çok katlı çelik yapılarda yatay deplasmanın diyagonallerle kontrolü. Osmangazi Üniversitesi Müh. Mim. Fak. Dergisi, X(1), 5970.

Özçelik, R. (2016). Burkulması engellenmiş çelik çaprazlar. Pamukkale Üniversitesi Mühendislik Bilimleri Dergisi, 22(3), 160-170.

Sta-Steel, (2019). Structural analysis for steel structure. ver.1.3.0.3. https://www.sta4.net/steeldefault.aspx

TBEC. (2019). Turkey Building Earthquake Code. Afet ve Acil Durum Yönetimi Başkanlığı, Ankara, Türkiye.

TS-498. (1997). Yapı Elemanlarının Boyutlandırllmasında Alınacak Yüklerin Hesap Değerleri. Türk Standartları Enstitüsü, Ankara, Türkiye.

Yelgin, N. A. ve Bulut, B. M. (2016). Merkezi çaprazlı ve dışmerkez çaprazlı çok katlı binaların Eurocode EC1, EC3, EC4 ve EC8 yönetmeliklerine göre dizayn kuralları ve süneklilik düzeylerinin karşılaştırılması, $4^{\text {th }}$ International Symposium on Innovative Technologies in Engineering and Science, Antalya, 142-149.

Yılmaz, A. (2020). Çelik çerçevelerde kullanılan dış merkezi çelik çapraz tiplerinin dügüm noktası birleşim detayına ve çerçeve davranışına etkisinin incelenmesi. Yüksek Lisans Tezi, Karabük Üniversitesi Lisansüstü Eğitim Enstitüsü, Karabük. 